\title{
Service Innovation in the Hospitality Industry
}

\author{
Girish K. Nair, Lakshmi C. Radhakrishnan
}

\begin{abstract}
The notion of service innovation has gained significant source of competitive advantage to any organization, in general, and also to firms in the hospitality industry. Any organization desiring to succeed must continually seek to create innovative products or services to gain and sustain an edge in the increasingly competitive market environment. This paper reviews extant literature associated with service innovation from two perspectives. A general literature review of the concepts associated with service innovation is performed drawing attention to such items as, the concept of service innovation; the definitions of service innovation; the differences between product and service innovation; the dimensions of service innovation; the drivers of service innovation; patterns of service innovation; effects of service innovation; and service innovation success factors. Second, a literature review associated with service innovation in the hospitality industry is undertaken. This latter review draws attention to the benefits of service innovation in the hospitality industry; the types of innovations in hospitality firms; and summarizes the findings of recent studies on service innovation in hospitality firms. Overall, the study found evidence of significant research attention to service innovation in the context of services in the hospitality industry. Moreover, it was found that some regions or countries, such as Europe and the Far East (Taiwan, in particular) appeared to be the recipients of greater attention in service innovation literature associated with the hospitality industry
\end{abstract}

Keywords:. Service innovation, literature review, dimensions, hospitality industry, hotels

\section{INTRODUCTION}

The hospitality industry is conventionally understood as the industry defined and prescribed by the services provided by hotels, restaurants and cafés (den Hertog, Gallouj, \& Segers, 2011). Hospitality businesses, and indeed any business at all, desiring to survive in the marketplace are required constantly to transform and renew their portfolio of services (or products) to satisfy the varying demands and desires of their intended market segments (Ottenbacher, 2007). For instance, in response to the dynamism of the environment it operates in, a hospitality firm may ponder the necessity to include a new brand to its scope. Additionally, a hotel may be compelled to create new services to ensure that hotel rooms remain occupied even during non-peak seasons or to maintain positive customer relationships. Consequently, complex marketing techniques, such as the capacity to effectively develop innovations, are required for hospitality businesses to remain successful. It could be inferred then that innovations are essential not merely to ensure survival but also for enduring success and stability (Cooper \& Edgett, 1999).

As stated by Burgelman, Maidique, and Wheelwright (2009): "innovations are the outcome of the innovation process, which can be defined as the combined activities leading to new, marketable products and services and/or new production and delivery systems". Innovations in the hospitality business can range from true innovations, that is, services that are absolutely new with a completely new market, to somewhat insignificant alterations to current services (Ottenbacher, 2007). In the context of hotels and other hospitality firms, a form of innovation that has been reported to be a particular source of competitive advantage is service innovation (Ottenbacher \& Gnoth, 2005). This is due to the fact that novel services can aid in attracting new customers, enhance the loyalty of existing customers, develop new opportunities in the market, and increase the sales revenue and profitability of hospitality firms (Huang, 2013; Nicolau \& Santa-María, 2013).

\section{LITERATURE REVIEW}

\section{A. The concept of service}

Prior to investigating the notion of service innovation, in general, and in the hospitality industry, in particular, the concept of service will be first introduced. The concept of service or the service concept has been defined as "a prototype for service, covering the needs of the customer and the design of the service" (Edvardsson \& Olsson, 1996). Moreover, it has been offered that the service concept is the core component neglected in the study of service design (Goldstein, Johnston, Duffy, \& Rao, 2002). Agarwal, Erramilli, \& Dev (2003) suggested that hotels must constantly revamp their services to customers in order to offer service quality that is better than their customers and more importantly, to maintain their competitive edge, a matter that illustrates the worth of innovation for services. Goldstein et al., (2002) also offered that the "how" and "what" of service design are integrated by the concept of service while taking both the needs of customers and the firm's strategic intent into account.

Revised Manuscript Received on October 31, 2019.

* Correspondence Author

Girish K. Nair*, Associate Professor \& Programme Leader, International Hospitality Management, Stenden Qatar, University of Applied Sciences, Doha, Qatar.Email:gknair75@gmail.com; gnair@stenden.edu.qa

Lakshmi C. Radhakrishnan, Assistant Professor \& Assistant Dean of Business, American College of Dubai, UAE. Email: Lakshmi.radhakrishnan@acd.ac; lakkshmicradhakrishnan@gmail.com 


\section{Service Innovation in the Hospitality Industry}

\section{B. Service innovation}

The concept of service innovation was first investigated by Barras (1986) who offered the features of services. Additionally, he suggested an abstract model for innovation of processes in services founded on the notion of the "reverse product cycle". Service innovation has also been studied by, among others, de Vries (2006), Evangelista and Savona (2003), Gallouj and Savona (2009), Gallouj and Weinstein (1997), Hipp and Grupp (2005), Lu and Tseng (2010), Sundbo (1997), and Verma, Anderson, Dixon, Thompson, and Victorino (2008). For instance, service innovation was viewed by Gallouj and Weinstein (1997) as any variation that influences one (or more) stipulations of one (or more) service features. The accomplishment of such variations is founded on 'one of a number of 'operations': addition, subtraction, association, dissociation, or formatting. These operations lead to different 'models' of innovation: radical, ameliorative, incremental, re-combinative, and formalized" (Gallouj \& Savona, 2011). Similarly, Michel, Brown, and Gallan (2008) posited that service innovation can be perceived to be a variation in the customer's role and the process of value creation. In his doctoral thesis, den Hertog (2010) defined a service innovation as "a new service experience or service solution in one or several of the following dimensions: new service concept, new customer interaction, new value system/business partners, new revenue model, new organizational or technological service delivery system".

Gallouj and Weinstein (1997) pointed out that the accomplishment of service innovation was difficult due to two significant factors. First, the origins of the theory of innovation can be traced to the study of technological innovation in the manufacturing industry. Second, service activities have definite features and their outcomes are typically non-tangible, consequently innovation in services is challenging to scrutinize and evaluate. Verma, R., Anderson, C., Dixon, M., Thompson, G., \& Victorino, L. (2008), after a roundtable session with scholars and industry practitioners, submitted three principles of service innovation. These are: possessing a customer focus with the objective of going beyond customer expectations, (2) possessing a process focus, with the objective of boosting productivity, such as the use of new methods or technologies to organize the innovation process, or (3) employing an attitude of continuous improvement to carrying out business, such as keeping up with the latest trends in the service industry. Good quality plagiarism software/ tool

\section{Product versus service innovation}

Several authors have examined the differences and similarities between product and service innovation with the objective of understanding whether models associated with product innovation (or new product development) can be utilized for service innovation (new service development) and vice versa. A few studies are summarized in Tables 1 and 2 .

Table- I: Differences between product and service innovation

\begin{tabular}{|l|c|}
\hline \multicolumn{1}{|c|}{ Authors } & $\begin{array}{c}\text { Differences between product and service } \\
\text { innovation }\end{array}$ \\
\hline $\begin{array}{l}\text { Mendonca, Pereira, \& } \\
\text { Godinho (2004) }\end{array}$ & Services cannot be protected via patents \\
\hline
\end{tabular}

\begin{tabular}{|c|c|}
\hline Griffin (1997) & $\begin{array}{l}\text { Service Innovation takes less time than } \\
\text { product innovation concept generation in the } \\
\text { development process is more frequent in new } \\
\text { service development than in new product } \\
\text { development processes are less complex } \\
\text { (easier) than in manufactured goods firms } \\
\text { New service development reports to the } \\
\text { marketing function, rather than to the SBU } \\
\text { level. }\end{array}$ \\
\hline Johne \& Storey (1998) & $\begin{array}{l}\text { New service development is, conceptually, } \\
\text { more complex than new product development }\end{array}$ \\
\hline $\begin{array}{l}\text { Froehle, Roth, Chase, \& } \\
\text { Voss (2000) }\end{array}$ & $\begin{array}{l}\text { Cross-functional teams are not related to a } \\
\text { higher development programs speed in new } \\
\text { service development, contrary to new product } \\
\text { development. }\end{array}$ \\
\hline $\begin{array}{l}\text { de Brentani (2001); } \\
\text { Martin \& Horne (1993) }\end{array}$ & $\begin{array}{l}\text { Formal new service development process is } \\
\text { less important than in manufacturing. }\end{array}$ \\
\hline Djellal \& Gallouj (2001) & $\begin{array}{l}\text { Testing of innovations more difficult for } \\
\text { services. }\end{array}$ \\
\hline $\begin{array}{l}\text { Henard \& Szymanski } \\
(2001)\end{array}$ & $\begin{array}{l}\text { Higher importance of market synergy, lower } \\
\text { importance of structured formal development } \\
\text { process, lower importance of cross-functional } \\
\text { communication in new service development. }\end{array}$ \\
\hline Hollenstein (2003) & $\begin{array}{l}\text { R\&D levels are lower in services than in } \\
\text { manufacturing. }\end{array}$ \\
\hline Tether (2005) & $\begin{array}{l}\text { Manufacturers tend to source new technology } \\
\text { through their internal R\&D departments } \\
\text { while, in service firms, new technology is } \\
\text { more often sourced through customers and } \\
\text { suppliers or external intellectual property. } \\
\text { Manufacturers tend to focus on technological } \\
\text { issues and R\&D, while services are more } \\
\text { likely to emphasize the skills of their } \\
\text { workforce. }\end{array}$ \\
\hline Hipp \& Grupp (2005) & $\begin{array}{l}\text { Internal R\&D is less important than in new } \\
\text { product development, more departments and } \\
\text { project teams involved in new service } \\
\text { development than in new product } \\
\text { development, service innovation more } \\
\text { incremental than product innovation. }\end{array}$ \\
\hline $\begin{array}{l}\text { Nijssen, Hillebrand, } \\
\text { Vermeulen, \& Kemp } \\
(2006)\end{array}$ & $\begin{array}{l}\text { Willingness to change existing routines is } \\
\text { more important in new service development } \\
\text { than in new product development, R\&D } \\
\text { strength is more positively related to } \\
\text { developing new services than to developing } \\
\text { new products; willingness to give up general } \\
\text { organizational dimensions is more positively } \\
\text { related to new product development than to } \\
\text { new service development. }\end{array}$ \\
\hline
\end{tabular}

Table- II: Similarities in Product and Service Innovation

\begin{tabular}{|l|l|}
\hline \multicolumn{1}{|c|}{ Author } & Similarities in product and service innovation \\
\hline de Brentani (1989) & $\begin{array}{l}\text { How to measure success, importance of } \\
\text { market orientation, a formal new service } \\
\text { development process, project synergy, } \\
\text { superior service offering. }\end{array}$ \\
\hline Martin \& Horne (1993) & $\begin{array}{l}\text { Customer involvement similarly important } \\
\text { and present as in new product development. }\end{array}$ \\
\hline de Brentani \& Ragot & Formal development process. \\
\hline Griffin (1997) & $\begin{array}{l}\text { Strategies are important to both innovation in } \\
\text { manufacturing and service innovation, leaders } \\
\text { in development projects are generally project } \\
\text { managers, multi-functional teams are } \\
\text { important to both new product development } \\
\text { and new service development, finding } \\
\text { appropriate rewards is similarly difficult in } \\
\text { new service development and new product } \\
\text { development. }\end{array}$ \\
\hline
\end{tabular}




\begin{tabular}{|l|l|}
\hline Froehle et al. (2000) & $\begin{array}{l}\text { Cross-functional team structures and } \\
\text { effectiveness of development efforts, } \\
\text { formalized development processes, } \\
\text { IT-enabled development process. }\end{array}$ \\
\hline $\begin{array}{l}\text { Meyer \& DeToreb } \\
(2001)\end{array}$ & $\begin{array}{l}\text { Platform-based product development } \\
\text { strategies are also applicable to services. }\end{array}$ \\
\hline Hollenstein (2003) & $\begin{array}{l}\text { Level of human resources equally high, } \\
\text { similar use of IT. }\end{array}$ \\
\hline Tether (2005) & $\begin{array}{l}\text { Innovation patterns exist which are more often } \\
\text { found in services than in manufacturing (and } \\
\text { vice versa), but these patterns are not unique } \\
\text { to services or manufacturing, respectively. }\end{array}$ \\
\hline Nijssen et al. (2006) & $\begin{array}{l}\text { Incremental product and service innovation } \\
\text { do not require process innovation; both new } \\
\text { products and new services may or may not } \\
\text { affect current sales. }\end{array}$ \\
\hline
\end{tabular}

\section{Dimensions of service innovation}

Various terms and concepts, or dimensions have been utilized in the study of service innovation to illustrate where service innovation. For example, Gadrey, Gallouj, \& Weinstein (1995) used five dimensions namely, innovation in service products; architectural innovations; modifications of existing services; innovations in processes; and organizations for existing services. On the other hand, Gallouj and Weinstein (1997) provided four dimensions: service outcome characteristics; service provider competencies; service provider technology; and client competencies. Sirilli and Evangelista (1998) utilized product innovation and process innovation as dimensions. den Hertog (2000) suggested four dimensions: conceptual innovation; client interface innovation; service delivery innovation / organizational innovation; and technological options. Van der Aa and Elfring (2002) submitted technological and organizational innovation as the dimensions of service innovation. Again, Sundbo (2003) offered four dimensions namely, product innovation; process innovation; organizational innovation; and market innovation. Drejer (2004) suggested external relationship and expertise-field innovation while Dolfsma (2004) suggested ad-hoc and organizational innovation. Djellal and Gallouj (2005) offered constituent services; mediums or targets of service provision; service characteristics or utilities; achieved or sought: competencies of the service providers. The dimensions offered by de Vries (2006) were service outcome characteristics; service provider competencies; service provider technology; client competencies; and client technology. Sundbo, Orfila-Sintes, and Sørensen (2007) suggested product innovation, process innovation, market innovation, organizational innovation, technological innovation, and widened services.

\section{E. Drivers of service innovation}

Using the lens of service-dominant logic (SDL) to examine service innovation, Ordanini \& Parasuraman (2011) proposed that there were three drivers of service innovation namely, "collaborative competences, a dynamic capability of customer orientation, and knowledge interfaces". Collaborative competences comprise collaboration with customer and business partner and indicate the significance of customers and business partners in the process of service innovation. On the other hand, a dynamic capability of customer orientation signifies the need for organizations to be concurrently concerned with learning and customers (Vargo \& Lusch, 2004). Combining customer orientation with innovative orientation to develop a dynamic capability of customer orientation will contribute to service innovation (Menguc \& Auh, 2006; Ordanini \& Parasuraman, 2011). The third driver knowledge interfaces can be defined as "a set of social and physical conditions facilitating the transference of knowledge within and among organizations" (Sherwood \& Covin, 2008). These interfaces guarantee the collection, assimilation, integration, and dispersion of knowledge (Madhavan \& Grover, 1998). Ordanini \& Parasuraman (2011) suggest that knowledge interfaces involve employee collaboration and mechanisms (i.e., prescribed procedures and frameworks that assist the gathering, examination, synthesis, and distribution of knowledge) to integrate knowledge from various sources (e.g., customers, business partners, and also employees).

The measure of service innovation performance is essentially the performance of the firm - growth in revenues per room and the growth in the EBIT (earnings before interest and taxes)-to-sales ratio Ordanini and Parasuraman (2011) utilized data from a sample of luxury hotels to test this framework and found that innovation volume but not radicalness was fostered by collaborating with customers; radicalness but not innovation volume was fostered by collaborating with business partners; innovative radicalness is affected by a firm's customer orientation both directly and in interaction with innovative orientation; both innovation volume and radicalness are enhanced by collaboration with contact employees; innovation radicalness (but not volume) is affected by the use of knowledge integration mechanisms; and the two performance measures are influenced significantly but somewhat differently by both innovation outcomes.

\section{F. Patterns of service innovation}

den Hertog (2010) presented the different roles played by suppliers, and service and client firms in service innovation. These different roles contribute to various patterns of service innovation. The patterns refer to the different ways in which these three actors are connected to each other. The five patterns are supplier-dominated innovation, innovation within services, client-led innovation, innovation through services, and paradigmatic innovations. den Hertog (2010) points out that these forms of innovation were unnoticed for a long time as they generally are more conceptual in nature. Client-led innovations refer to innovations that are the outcome of the response of a service firm to the distinctly expressed needs of its clients. It must be noted that while all innovations are a response to an apparent need from the market, it is more definite in the case of some service innovations. The fourth pattern, innovation through services, refers to service firms influencing the process of innovation occurring at the client firm.

\section{G. Patterns of service innovation}

den Hertog (2010) presented the different roles played by suppliers, and service and client firms in service innovation. These different roles contribute to various patterns of service innovation. 


\section{Service Innovation in the Hospitality Industry}

The patterns refer to the different ways in which these three actors are connected to each other. The five patterns are supplier-dominated innovation, innovation within services, client-led innovation, innovation through services, and paradigmatic innovations. den Hertog (2010) points out that these forms of innovation were unnoticed for a long time as they generally are more conceptual in nature. Client-led innovations refer to innovations that are the outcome of the response of a service firm to the distinctly expressed needs of its clients. It must be noted that while all innovations are a response to an apparent need from the market, it is more definite in the case of some service innovations. The fourth pattern, innovation through services, refers to service firms influencing the process of innovation occurring at the client firm.

\section{H. Effects of service innovation}

Aas and Pedersen (2010) identified 278 individual firm-level effects of service innovation and grouped them into five categories namely, business process effects, relationship effects, financial performance effects, capability effects, and competitiveness effects. Using the description provided by Rummler and Brache (1995) for business processes, that is, that "a business process is a series of steps designed to produce a product or service". Aas and Pedersen (2010) further categorized the category business process effects into six categories sub-effects. That is, internal business process effects, productivity effects, internal cost effects, flexibility effects, service delivery capacity effects, and risk reduction effects. Financial performance effects indicate the enhanced financial performance of an innovating organization due to service innovation. The sub-effects associated with this category of effects are: general financial performance effects, sales (of existing goods or services) effects, sales (of new services) effects, market share effects, and effects on the market value of the firm (Aas \& Pedersen, 2010). The category capability effects relates to the part played by service innovation in enhancing or reinforcing the internal capabilities of an innovator. The sub-categories associated with capability-related effects are: learning effects, employee growth effects, culture effects, and employee satisfaction effects (Aas \& Pedersen, 2010).Competitiveness effects related to the manner in which the competitiveness of an innovating firm may be enhanced by service innovation. The sub-categories identified in this regard are effects on the competitive position, creation of new markets effects, effects on the ability to survive, and strategic performance effects (Aas \& Pedersen, 2010). It has also been recognized that service innovation may have an impact on stakeholders external to the innovating firm.

\section{Service innovation success factors}

Ottenbacher (2007) summarized prior research on the success factors that could be associated with service innovation. For example, de Brentani (2001) suggested four categories of success factors related to product, market, process, and organization. Concerning success factors associated with the product, Cooper, Easingwood, Edgett, Kleinschmidt, and Storey (1994) submitted that scholars have recognized the comparative advantage of a service or product

as a significant basis of success. The primary success factor from a product development perspective has been recognized to be product advantage. However, from a services perspective, while the service product is significant, it is not believed to be the crucial factor affecting success. In its place, the observed quality of customer interaction is deemed to be of greater significance for new services (de Brentani, 2001).

Factors associated with the market encompass market awareness and market appeal (de BrentaniRagot, 1996; Edgett, 1994). Moreover, Selden and MacMillan (2006) suggested that organizations should constantly enhance their awareness of their customers to encompass the identity of the customers and their specific desires and requirements. Market-orientation and competent development practices, employee engagement, preparation for service introduction, successful communication, and process management are some of the success factors associated with process (Atuahene-Gima, 1996; de Brentani, 2001; Leiponen, 2006). The success of a new service is strongly associated with the usage of a comprehensive, prescribed, and competent process. Also significant are good inter-departmental communication all through the process of development of a new service, top management support, and the skilled leadership (de Brentani, 2001). Unsuccessful outcomes have been associated with poor understanding of customers and competitors. Consequently, employee engagement during the process of new service development is especially important due to their awareness of customer needs and their proficiency in enhancing quality of the service (Ottenbacher \& Gnoth, 2005). Effective innovators are successful communicators who can increase customer awareness of a new service and assure customers of its advantages (Cooper \& Edgett, 1999).

\section{J. Benefits of service innovation in the hospitality Industry}

Taking the example of hotels, it is evident that the key product of firms in the hospitality industry is service. The hotel industry, in particular, places emphasis on the aspects of intensive labour, immediate utilization, and an enjoyable boarding experience (Canina, Enz, \& Harrison, 2005). These peculiar features ensure that great challenges are encountered by the hotel industry. Moreover, hotels bear great stress in offering superior service to customers.

O'Cass and Sok (2013) drew attention to the aid provided by service innovation in the creation of superior value for customers. Since the service-related expectations and needs of customers are subject to change, hotels are required to continually seek to create new services to develop greater customer value and also sustain their competitive edge. Thus, it is evident that service innovation must be implemented by hotels to offer services to customers that generate an apparent value that is greater than their price. Hotels must combine numerous services or utilize original means to integrate existing services to meet practical and pleasurable customer needs (Tang et al., 2013). Service innovation positively influences the value to customers as offered by service organizations (O'Cass \& Sok, 2013). 
Not only does the creation of new services serve to offer customers a distinctive experience and exceptional fundamental value, it also permits hotels to distinguish themselves from their competition and improves their reputation and quality of service (Möller, Rajala, \& Westerlund, 2008; O'Cass \& Sok, 2013; Ottenbacher \& Gnoth, 2005; Paswan, D'Souza, \& Zolfagharian, 2009). Thus, hotels must have the capacity to constantly revamp their services to continue to be ahead of their competitors and to preserve the position of a market leader

\section{K. Recent studies on service innovation in the hospitality industry}

Hu, Horng, and Sun (2009) studied service innovation in the context of international tourist hotels in Taiwan from the perspective of exploring issues associated with knowledge sharing, service innovation performance, and the role played by organizational teams in enhancing knowledge sharing and service innovation performance in organizations. They found that robust and significant relationships among knowledge sharing, service innovation performance, and team culture. Nicolau and Santa-María (2013) analyzed the impact of hotel innovations on the market value of the hotel. The outcomes of the study demonstrated that innovations are believed to have a favorable influence on a hotel's future sales. From the perspective of types of innovation, marketing and process innovations were found to have a more favorable influence on hotel market value than organization and product innovations which was supported by the probable cost variances among innovations. Cheng and Liu (2015) studied the typology of service innovation in the food and beverage industry in Taiwan. Their study found that there were two categories of service innovation, that is, service innovation principles and service innovation regimes, which included five subcategories namely, integration, expandability, details, ICT, and non-ICT. Chang, Gong, and Shum (2011) investigated the manner in which hospitality companies can encourage incremental and radical innovation by means of human resource management (HRM) practices. Their study utilized data independent hotels and restaurants operating in the People's Republic of China. The outcomes reveal that both the hiring of primary customer-facing employees with multiple skills and the imparting of multiple skills to primary customer-facing employees through training significantly and positively influenced incremental and radical innovation in the sample companies. Khuong and Giang (2014) explored the factors influencing service innovation and the impact of innovation practices on the manner in which guests perceive value and their intent to repeatedly visit a hotel by surveying hotel guests in three to five-star hotels in Ho Chi Minh City, Vietnam. They found that the intention of a guest to return was favorably associated with hotel types, marketing-focused innovation, price innovation, process innovation, customization of service, and use of information technology. Moreover, factors, such as hotel type, pricing innovation, and process innovation, both directly and indirectly influenced the return intention of guests.. The outcomes of the study revealed that non-technological innovation can result in product differentiation along with cost leadership just as proficiently as technological innovation. In another study of Taiwanese hotels, Tseng, Kuo, and Chou (2008) attempted to categories the configurations of innovation using two-step cluster analysis and to identify the type of innovation configuration that would lead to increased performance. Cheng, Xiang, Sher, and Liu (2016) adopted the viewpoints of artistic intervention and intellectual capital to explore the facets of intellectual capital management by studying the case of a successful art-focused Taiwanese hotel. They found that hotel managers must place emphasis on the significance of managing a hotel's tangible and intangible resources, embedded both in the hotels' employees and processes. de la Peña, Núñez-Serrano, Turrión, and Velázquez (2016) assessed the influence of innovative activity in the hotel industry on the readiness of consumers to pay in a study of a representative sample of Cuban hotels, taking a large number of attributes of hotels and rooms into account. They estimated a hedonic price function where innovation was indirectly recognized by means of particular features associated with hotel innovativeness. The outcomes of the study illustrate the significance of the features connected to innovation and internationalization on the regulation of room prices in Cuban hotels.

\section{CONCLUSION}

Thus, it was evident that there was significant research attention to service innovation in the context of services in the hospitality industry. Also, it could be seen that some regions or countries, such as Europe and the Far East (Taiwan, in particular) appeared to be the recipients of greater attention in service innovation literature associated with the hospitality industry. Therefore, it is suggested that future researchers take other regions (e.g., the Middle East, Australasia, etc.) into consideration while studying service innovation. Another aspect that can be explored by future researchers is deeper investigations into the manner of service innovation implementation in different organization types in the hospitality industry, such as hotels, restaurants, cafes, etc.

\section{REFERENCES}

1. Aas, T. H., \& Pedersen, P. E. (2010). The firm-level effects of service innovation: a literature review. International Journal of Innovation Management, 14(05), 759-794.

2. Agarwal, S., Erramilli, M. K., \& Dev, C. S. (2003). Market orientation and performance in service firms: role of innovation. Journal of Services Marketing, 17(1), 68-82.

3. An, Y., \& Duan, Z. (2008, October). Factors Affecting Service Innovation in the Hospitality Industry. In Wireless Communications, Networking and Mobile Computing, 2008. WiCOM'08. 4th International Conference on (pp. 1-4). IEEE.

4. Atuahene-Gima, K. (1996). Market orientation and innovation. Journal of Business Research, 35(2), 93-103.

5. Barras, R. (1990). Interactive innovation in financial and business services: the vanguard of the service revolution. Research Policy, 19(3), 215-237.

6. Burgelman, R. A., Maidique, M. A., \& Wheelwright, S. C. (2009) Strategic management of technology and innovation (Vol. 2). Chicago IL: Irwin.

7. Canina, L., Enz, C. A., \& Harrison, J. S. (2005). Agglomeration effects and strategic orientations: Evidence from the US lodging industry. Academy of Management Journal, 48(4), 565-581.

8. Chang, S., Gong, Y., \& Shum, C. (2011). Promoting innovation in hospitality companies through human resource management practices. International Journal of Hospitality Management, 30(4), 812-818. 


\section{Service Innovation in the Hospitality Industry}

9. Cheng, J. S., \& Liu, C. W. (2015). Typology of Service Innovation in the Food and Beverage Industry in Taiwan. Universal Journal of Management, 3(7), 291-297.

10. Cheng, J. S., Xiang, Y., Sher, P. J., \& Liu, C. W. (2016). Artistic intervention, intellectual capital, and service innovation: a case study of a Taiwan's hotel. Service Business, 1-33.

11. Cooper, R. G., Easingwood, C. J., Edgett, S., Kleinschmidt, E. J., \& Storey, C. (1994). What distinguishes the top performing new products in financial services. Journal of Product Innovation Management, 11(4), 281-299.

12. Cooper, R. G., \& Edgett, S. J. (1999). Product development for the service sector. Cambridge, MA: Perseus.

13. de Brentani, U. (1989). Success and failure in new industrial services. Journal of Product Innovation Management, 6(4), 239-258.

14. de Brentani, U. (2001). Innovative versus incremental new business services: different keys for achieving success. Journal of Product Innovation Management, 18(3), 169-187.

15. de Brentani, U., \& Ragot, E. (1996). Developing new business-to-business professional services: what factors impact performance? Industrial Marketing Management, 25(6), 517-530.

16. de la Peña, M. R., Núñez-Serrano, J. A., Turrión, J., \& Velázquez, F. J (2016). Are innovations relevant for consumers in the hospitality industry? A hedonic approach for Cuban hotels. Tourism Management, 55, 184-196.

17. de Vries, E. J. (2006). Innovation in services in networks of organizations and in the distribution of services. Research Policy, 35(7), 1037-1051

18. den Hertog, P. (2000). Knowledge-intensive business services as co-producers of innovation. International Journal of Innovation Management, 4(04), 491-528.

19. den Hertog, P. (2010). Managing service innovation: firm-level dynamic capabilities and policy options. (Doctoral thesis, University of Amsterdam).

20. den Hertog, P., Gallouj, F., \& Segers, J. (2011). Measuring innovation in a 'low-tech'service industry: the case of the Dutch hospitality industry. The Service Industries Journal, 31(9), 1429-1449.

21. Djellal, F., \& Gallouj, F. (2001). Patterns of innovation organisation in service firms: postal survey results and theoretical models. Science and Public Policy, 28(1), 57-67.

22. Djellal, F., \& Gallouj, F. (2005). Mapping innovation dynamics in hospitals. Research policy, 34(6), 817-835.

23. Dolfsma, W. (2004).The process of new service development: Issues of formalization and appropriability. ERIM Report Series Research in Management. Erasmus Research Institute of Management, Rotterdam.

24. Drejer, I. (2004). Identifying innovation in surveys of services: a Schumpeterian perspective. Research Policy, 33(3), 551-562.

25. Edvardsson, B., \& Olsson, J. (1996). Key concepts for new service development. Service Industries Journal, 16(2), 140-164.

26. Evangelista, R., \& Savona, M. (2003). Innovation, employment and skills in services. Firm and sectoral evidence. Structural Change and Economic Dynamics, 14(4), 449-474.

27.Froehle, C. M., Roth, A. V., Chase, R. B., \& Voss, C. A. (2000) Antecedents of new service development effectiveness: an exploratory examination of strategic operations choices. Journal of Service Research 3(1), 3-17.

28.Gadrey, J., Gallouj, F., \& Weinstein, O. (1995). New modes of innovation: how services benefit industry. International Journal of Service Industry Management, 6(3), 4-16.

29.Gallouj, F. (1998). Innovating in reverse: services and the reverse product cycle. European Journal of Innovation Management, 1(3), 123-138.

30.Gallouj, F., \& Savona, M. (2009). Innovation in services: a review of the debate and a research agenda. Journal of Evolutionary Economics, 19(2), 149.

31.Gallouj, F., \& Savona, M. (2011). Towards a theory if innovation in services: a state of the art. In Gallouj, F. \& F. Djellal (Eds.), The Handbook of Innovation and Services. Edward Elgar Publishing Inc., Northampton, US.

32.Gallouj, F., \& Weinstein, O. (1997). Innovation in services. Research Policy, 26(4-5), 537-556.

33.Goldstein, S. M., Johnston, R., Duffy, J., \& Rao, J. (2002). The service concept: the missing link in service design research?. Journal of Operations Management, 20(2), 121-134.

34. Griffin, A. (1997). PDMA research on new product development practices: Updating trends and benchmarking best practices. Journal of Product Innovation Management, 14(6), 429-458.

35. Hariandja, E. S. (2011). The Relationship between Service Innovation, Marketing Communication, and Performance in Hospitality

Industries-A Conceptual Framework. Proceeding of Industria Engineering and Service Science, 20-21.

36.Henard, D. H., \& Szymanski, D. M. (2001). Why some new products are more successful than others. Journal of Marketing Research, 38(3), 362-375.

37.Hipp, C., \& Grupp, H. (2005). Innovation in the service sector: The demand for service-specific innovation measurement concepts and typologies. Research Policy, 34(4), 517-535.

38.Hollenstein, H. (2003). Innovation modes in the Swiss service sector: a cluster analysis based on firm-level data. Research Policy, 32(5), $845-863$

39.Huang, H. L. (2013). Performance effects of aligning service innovation and the strategic use of information technology. Service Business, 8(2), 171-195.

40.Johne, A., \& Storey, C. (1998). New service development: a review of the literature and annotated bibliography. European Journal of Marketing, $32(3 / 4), 184-251$

41.Khuong, M. N., \& Giang, T. H. (2014). The Effects of Service Innovation on Perceived Value and Guest's Return Intention--A Study of Luxury Hotels in Ho Chi Minh City, Vietnam. International Journal of Trade, Economics and Finance, 5(6), 503

42.Lu, I. Y., \& Tseng, C. J. (2010). A study of the service innovation activities of tourist hotels in Taiwan. International Journal of Organizational Innovation (Online), 3(1), 156.

43.Madhavan, R., \& Grover, R. (1998). From embedded knowledge to embodied knowledge: new product development as knowledge management. The Journal of Marketing, 1-12

44.Martin Jr, C. R., \& Horne, D. A. (1993). Services innovation: successful versus unsuccessful firms. International Journal of Service Industry Management, 4(1), 49-65.

45.Mendonça, S., Pereira, T. S., \& Godinho, M. M. (2004). Trademarks as an indicator of innovation and industrial change. Research Policy, 33(9), 1385-1404.

46.Menguc, B., \& Auh, S. (2006). Creating a firm-level dynamic capability through capitalizing on market orientation and innovativeness. Journal of the Academy of Marketing Science, 34(1), 63-73.

47.Meyer, M. H., \& DeToreb, A. (2001). Perspective: creating a platform-based approach for developing new services. Journal of Product Innovation Management, 18(3), 188-204.

48.Michel, S., Brown, S. W., \& Gallan, A. S. (2008). An expanded and strategic view of discontinuous innovations: deploying a service-dominant logic. Journal of the Academy of Marketing Science, 36(1), 54-66

49.Möller, K., Rajala, R., \& Westerlund, M. (2008). Service innovation myopia? A new recipe for client-provider value creation. California Management Review, 50(3), 31-48.

50.Nicolau, J. L., \& Santa-María, M. J. (2013). The effect of innovation on hotel market value. International Journal of Hospitality Management, 32 71-79.

51.Nijssen, E. J., Hillebrand, B., Vermeulen, P. A., \& Kemp, R. G. (2006) Exploring product and service innovation similarities and differences International Journal of Research in Marketing, 23(3), 241-251.

52.O'Cass, A., \& Sok, P. (2013). Exploring innovation driven value creation in B2B service firms: The roles of the manager, employees, and customers in value creation. Journal of Business Research, 66(8), 1074-1084.

53.Ordanini, A., \& Parasuraman, A. (2011). Service innovation viewed through a service-dominant logic lens: a conceptual framework and empirical analysis. Journal of Service Research, 14(1), 3-23

54.Orfila-Sintes, F., \& Mattsson, J. (2009). Innovation behavior in the hotel industry. Omega, 37(2), 380-394.

55.Ottenbacher, M. C. (2007). Innovation management in the hospitality industry: different strategies for achieving success. Journal of Hospitality \& Tourism Research, 31(4), 431-454.

56.Ottenbacher, M., \& Gnoth, J. (2005). How to develop successful hospitality innovation. Cornell Hotel and Restaurant Administration Quarterly, 46(2), 205-222.

57.Paswan, A., D'Souza, D., \& Zolfagharian, M. A. (2009). Toward a contextually anchored service innovation typology. Decision Sciences, 40(3), 513-540.

58. Rummler, G.A., \& Brache, A.P. (1995). Improving performance: Managing the white space in organizations. San Francisco: Jossey-Bass.

59.Selden, L., \& MacMillan, I. C. (2006). Manage customer-centric innovation-systematically. Harvard Business Review, 84(4), 108 
60.Sherwood, A. L., \& Covin, J. G. (2008). Knowledge acquisition in university-industry alliances: An empirical investigation from a learning theory perspective. Journal of Product Innovation Management, 25(2), 162-179.

61.Sirilli, G., \& Evangelista, R. (1998). Technological innovation in services and manufacturing: results from Italian surveys. Research Policy, 27(9), 881-899.

62.Sundbo, J. (1997). Management of innovation in services. Service Industries Journal, 17(3), 432-455.

63.Tang, T. W., Wang, M. C. H., \& Tang, Y. Y. (2013). Developing service innovation capability in the hotel industry. Service Business, 9(1), 97-113.

64.Tether, B. S. (2005). Do services innovate (differently)? Insights from the European innobarometer survey. Industry \& Innovation, 12(2), 153-184.

65.Tseng, C. Y., Kuo, H. Y., \& Chou, S. S. (2008). Configuration of innovation and performance in the service industry: evidence from the Taiwanese hotel industry. The Service Industries Journal, 28(7), 1015-1028.

66.Van der Aa, W., \& Elfring, T. (2002). Realizing innovation in services. Scandinavian Journal of Management, 18(2), 155-171.

67.Vargo, S. L., \& Lusch, R. F. (2004). Evolving to a new dominant logic for marketing. Journal of Marketing, 68(1), 1-17.

68.Verma, R., Anderson, C., Dixon, M., Thompson, G., \& Victorino, L. (2008). Key Elements in Service Innovation: Insights for the Hospitality Industry. Cornell Hospitality Roundtable Proceedings, 1(1), 6-12.

69.Victorino, L., Verma, R., Plaschka, G., \& Dev, C. (2005). Service innovation and customer choices in the hospitality industry. Managing Service Quality: An International Journal, 15(6), 555-576.

\section{AUTHORS PROFILE}

Dr. Girish K. Nair is the Program Leader of International Hospitality Management, Stenden Qatar, University of Applied Sciences. He received his Ph.D in Management in the areas of Financial Accounting and Industrial Economics from Banasthali University (Accredited by NAAC with 'A' Grade status) and Master's Degree in Commerce, International Business and Business Administration from India. He has more than 18 years of teaching, research, and administrative experience. Prior to joining Stenden University, he held the position of Senior Lecturer in Commerce in an 'A' Grade College in India. His primary research interests are in the areas of corporate finance, financial economics, and hospitality \& tourism management. He has several international and Indian domestic publications to his credit. He has also presented his research in many international and national conferences, workshops and seminars. In addition, he has acted as a chair for technical sessions at international and national conferences. He is also an International Examiner for Ph.D research at various universities in India. Dr. Nair is one of the Principal Investigators on NPRP research projects funded by QNRF in collaboration with Stenden Qatar University of Applied Sciences and Edinburgh Napier University, UK.

Dr. Lakshmi C. Radhakrishnan is the Dean of Research and Academic Accreditation at the American College of Dubai. She has been awarded her $\mathrm{PhD}$ in Business Administration from Manonmaniam Sundaranar University in India. With more than 5 years of teaching and overall 10 years of corporate experience, Lakshmi is an ardent researcher in the areas of Educational Pedagogy Management, Sustainability and Organizational Behavior apart from her area of study in Human Resources Management .She is an internationally published scholar in several peer-reviewed journals and has also presented her research in many international and national conferences, workshops and seminars. In addition, she is also an internationally published author for four fiction genre novels and anthology. She is a reviewer in the Arabian Journal of Business Management and Review and a member of the International Centre for Academic Integrity, USA. Lakshmi is also a specialist in higher educational pedagogy and framework management certified by Harvard, UK through the Derek-Bok Centre for Teaching and Learning. 